\title{
Antimicrobial activity screening of endophytic fungi extracts isolated from brown algae Padina sp.
}

\author{
Dian Handayani ${ }^{*}$, Nita Ananda ${ }^{1}$, Muh. Ade Artasasta ${ }^{1}$, Rustini Ruslan ${ }^{1}$, Okmes Fadriyanti $^{2}$, Trina Ekawati Tallei ${ }^{3}$ \\ ${ }^{1}$ Sumatran Biota Laboratory, Faculty of Pharmacy, University of Andalas, Kampus Limau Manis, Padang, Indonesia. \\ ${ }^{2}$ Faculty of Dentistry, University of Baiturahmah, Padang, Indonesia. \\ ${ }^{3}$ Department of Biology, Faculty of Mathematics and Natural Sciences, Sam Ratulangi University, Manado, Indonesia.
}

\begin{tabular}{l}
\hline ARTICLE INFO \\
\hline Received on: $17 / 09 / 2018$ \\
Accepted on: 12/02/2019 \\
Available online: 30/03/2019 \\
\\
\hline Key words: \\
Antimicrobial activity, \\
brown algae, marine algae- \\
derived fungi, molecular \\
characterization, Trichoderma \\
harzianum, Padina sp.
\end{tabular}

\section{INTRODUCTION}

Secondary metabolite compounds, which are produced by marine-derived fungi, are potential sources of novel antibiotic lead and bioactive compounds. As the success in finding the antibiotic penicillin as a chemical compound produced by the fungus Penicillium notatum, various types of fungi are currently seriously studied in the discovery of bioactive compounds (Hawksworth, 1991). Marine-derived endophytic fungi living in the internal tissue without causing a negative effect to their host have proven to be prolific sources of bioactive natural products with unique structures and potent pharmaceutical activities (Bacon and White, 2000; Bugni and Ireland, 2004; Strobel and Daisy, 2003). Fungi have been obtained from virtually every possible marine

\section{"Corresponding Author}

Dian Handayani, Sumatran Biota Laboratory, Faculty of Pharmacy, University of Andalas, Kampus Limau Manis, Padang, Indonesia. E-mail: dianhandayani@phar.unand.ac.id habitat, including marine plants (algae, driftwood, and mangrove plants), marine invertebrates (sponges, corals, ascidians, and holothurians), and vertebrates (mainly fish). Among them, algae are one of the most prevalent sources of marine-derived fungi for chemical studies. A number of previous studies reported that the diversity of fungi is influenced by the nutrients availability and other physicochemical conditions of the coastal ecosystem (Ashok et al., 2015).

Natural products of algal-derived endophytic fungal have been the subject of many chemical reports, especially in the past 10 years. Several new compounds have been isolated and identified with a wide range of biological properties, including anticancer, antibiotic, antiviral, antioxidative, and kinase inhibitory or activated activities (Flewelling et al., 2015; Rateb and Ebel, 2011, Singh et al., 2014). Varioxepine A, a new alkaloid contained $3 \mathrm{H}$-oxapine isolated from the marine algaderived fungus Paecilomyces variotti, for example, has potent antimicrobial activity against several human pathogenic bacteria with the minimal inhibitory concentration (MIC) values ranging 
from 16 to $46 \mu \mathrm{g} / \mathrm{ml}$ (Zhang et al., 2014). In addition, the study of Wong et al. (2015) revealed that endophytic fungi from marine algae Padina sp. have potent antimicrobial activity against some pathogenic microbes.

West Sumatera, Indonesia, has a high species diversity of marine algae but there are only a few reports on the screening of West Sumatran marine algae-derived fungi for antibacterial and antifungal activities. The present research was made to study the endophytic fungi isolated from marine algae, Padina sp. and its antimicrobial activity against $S$. aureus, E. coli, and C. albicans by using the agar diffusion method.

\section{MATERIALS AND METHODS}

\section{Sample preparation}

Padina sp. was collected from Nirwana Beach, Padang, West Sumatera, Indonesia. This marine brown alga was rinsed using sterile sterile sea water and immersed in $70 \%$ ethanol for $60-120$ seconds and then put in the plastic containing sterile sea water. It was then stored in the icebox and transported to the laboratory for further investigation (Kjer et al., 2010).

\section{Isolation of endophytic fungi from marine brown algae Padina sp.}

Padina sp. was cut into small pieces. Approximately 10 $\mathrm{g}$ of this sample was dispersed in sterile seawater until the volume on Erlenmeyer achieved $100 \mathrm{ml}$. The mixture was then diluted until $10^{-6} \mathrm{ml}$. One milliliter of the sample was poured aseptically onto SDA (SDA + Chloramphenicol) medium in the Petri dish. The plate was incubated for $5-7$ days at temperature $25^{\circ} \mathrm{C}-27^{\circ} \mathrm{C}$. Colonies which showed different shapes to others were regarded as different isolates and then purified by the scratch method to obtain pure single isolate (Kjer et al., 2010).

\section{Cultivation of pure fungi isolate in the medium of rice}

Fungi isolate in the Petri dish was cut $1 \times 1 \mathrm{~cm}$, and then cultured in rich medium and incubated at room temperature for 4-6 weeks. The fungi grow maximally when all part of rice was covered by the fungi isolate (Kjer et al., 2010).

\section{Extraction of a secondary metabolite of fungi isolate}

Pure isolate, which had been grown for 4-6 weeks, was extracted by maceration with ethyl acetate (EtOAc) with the ratio 1:1 for 24 hours and then filtered. The macerate of EtOAc was evaporated with a rotary evaporator to produce the extract of fungi. Then, the extract was ready to be screened for antimicrobial activity (Kjer et al., 2010).

\section{Screening for antimicrobial activity}

Screening for antimicrobial activity was tested against $S$. aureus, E. Coli, and C. albicans using the agar diffusion method. The extract was diluted with dimethyl sulfoxide (DMSO) to reach the concentration of $5 \%, 3 \%$, and $1 \%$. One piece of sterile disk paper $(6 \mathrm{~mm})$ was soaked in each of EtOAc extract concentration. DMSO was used for negative control and gentamicin disk as a positive control for bacteria and nystatin disk as a positive control for fungi. Zone of inhibition ( $\mathrm{mm})$ was measured after incubation at a temperature of $37^{\circ} \mathrm{C}$ for $18-24$ hours (Bauer et al., 1959).

\section{Phytochemical screening of endophytic fungi extract}

Phytochemical screening was done for all EtOAc endophytic fungi extracts by using the standard method of Tiwari et al. (2011). This method aims to know the alkaloid, phenolic, terpenoid, and steroid compound from each endophytic fungus extract.

\section{Alkaloid detection}

$0.5 \mathrm{ml}$ diluted hydrochloric acid $(10 \%)$ was used to dissolve $1 \mathrm{ml}$ extract then filtered. Furthermore, the $1 \mathrm{ml}$ filtrate was added with three to four drops of Mayer reagent. Positive alkaloid will be shown by the yellow color of the filtrate.

\section{Phenolic detection}

The extract $(1 \mathrm{ml})$ was dissolved with $0.5 \mathrm{ml}$ diluted hydrochloric acid $(10 \%)$ then filtered. The filtrate was then added with - three to four drops of ferric chloride solution. Positive phenolic will be shown by the blue color of the filtrate.

\section{Steroid and terpenoid detection}

The extract $(1 \mathrm{ml})$ was dissolved with chloroform then filtered. The filtrate was then added with one to two drops of acetic anhydride $(99 \%)$ and concentrated $\mathrm{H}_{2} \mathrm{SO}_{4}$. The positive steroid will be shown by the blue or purple color of the filtrate, while terpenoid will be indicated by the red color of the filtrate.

\section{Molecular identification}

\section{DNA extraction}

DNA extraction was conducted by the following modification method of Atashpaz et al. (2010). Once the fungus was grown in the SDA media for 24 hours, its cell biomass was then transferred to the microtube containing $500 \mu \mathrm{l}$ of lysis buffer. The mixture was centrifuged at $18,000 \mathrm{rpm}$ for 5 minutes at $4^{\circ} \mathrm{C}$. The filtrate was removed, and the pellet-contained DNA was dissolved with $50 \mu \mathrm{l}$ of TE buffer $\mathrm{pH}$ 8.0.

\section{Polymerase chain reactions (PCR) amplification and sequence of ITS-encoding gene}

PCR thermal cycler (KOD FX Neo, Toyobo, Japan) machine was used for PCR amplification. This PCR following PCR master mix protocol, KAPA2G Fast Ready mix PCR kit, with primer internal transcribed spacer (ITS) 1 (F 5'- TCC GTA GGT GAA CCT GCG G-3') and primer ITS4 (R 5'- TCC TCC GCT TAT TGA TAT GC-3'). The PCR amplification reaction is as follows: The reaction involved one cycle at $95^{\circ} \mathrm{C}$ for 5 minutes, followed by 35 cycles with a step of denaturation at $95^{\circ} \mathrm{C}$ for 30 seconds, step annealing at $55^{\circ} \mathrm{C}$ for 1 minute, and step extension at $72^{\circ} \mathrm{C}$ for 1 minute, followed by one cycle at $72^{\circ} \mathrm{C}$ for 6 minutes (Ferrer et al., 2001).

The PCR products were sent to first Base Malaysia for sequencing. The sequences were trimmed and assembled by using the BioEdit V.7.0.5 program. Furthermore, the sequences were subjected to BLAST on NCBI and species identification using the BOLD system. Neighbor-joining method was used for constructing the phylogenetic tree with a bootstrap value of 1,000 replication by using MEGA 7.0 software (Kumar et al., 2016).

\section{RESULTS AND DISCUSSION}

Our continuous research has been carried out to isolate the marine fungi, especially those from marine sponges. The 
screening of antimicrobial and anticancer activities of fungi extracts showed that it can be exploited as alternative sources for biomedical therapy (Artasasta et al., 2018; Handayani and Aminah, 2017; Handayani and Artasasta, 2017; Handayani et al., 2016;2018). Some marine sponge-derived fungi were proved to produce some bioactive compounds which are beneficial for health. The marine brown algal genus Padina are widely distributed throughout the tropics and are very easy to recognize in the field. Based on a study by Wong et al. (2015), endophytic fungi founded in Padina sp. were active against some pathogen microbes. Due to their different and unique living condition, Padina sp. collected from Indonesia was thought of having some different kinds of endophytic fungi which may lead to the new source of new chemical structures from marine algae. Based on antimicrobial activity that showed in Table 1, six extracts of fungi were active against $E$. coli and five extracts were active against $S$. aureus and $C$. albicans in the concentration of $5 \%$. Based on the diameter of the inhibition zone, there were two isolates showing the promising results, $\mathrm{Nita}_{3}\left(\mathrm{NT}_{3}\right)$ and $\mathrm{NT}_{9}$. The inhibition zone from the extract $\mathrm{NT}_{3}$ and $\mathrm{NT}_{9}$ against $S$. aureus was 17.09 and $12.8 \mathrm{~mm}$, respectively. However, against E. coli, only $\mathrm{NT}_{3}$ had good promising antibacterial with a diameter of inhibition zone of $13.60 \mathrm{~mm}$ and $\mathrm{NT}_{9}$ had no activity. Extract $\mathrm{NT}_{3}$ and $\mathrm{NT}_{9}$ against pathogenic fungus, $C$. albicans, also had good promising activity with a diameter zone of 20.98 and 11.1 $\mathrm{mm}$, respectively.

Compared to all endophytic fungi isolate, $\mathrm{NT}_{3}$ was the most active against all tested pathogenic microbes. Macroscopically, $\mathrm{NT}_{3}$ has white color at the upper and green color at the bottom, almost radial shape, and furred. Based on the molecular identification using the ITS region, the obtained DNA band was around 640 bp (Fig. 1). A BLAST search in NCBI-GenBank showed that the $\mathrm{NT}_{3}$ isolate had a maximum identity of $99 \%$ with $T$. harzianum. Using the BOLD system, $\mathrm{NT}_{3}$ isolate showed $99.63 \%$ similarity with $T$. harzianum. There is no enough morphological information about $T$. harzianum, but at the genus level, Trichoderma is known to have white, yellow, until green color, macroscopically. Trichoderma sp. is a

Table 1. Antimicrobial activity of EtOAc extract of endophytic fungi from marine algae Padina sp.

\begin{tabular}{|c|c|c|c|c|c|c|c|c|c|}
\hline \multirow{3}{*}{ Fungi code } & \multicolumn{9}{|c|}{ Zone of inhibition $(\mathrm{mm}) \pm$ standard deviation $(\mathrm{SD})$} \\
\hline & \multicolumn{3}{|c|}{ E. coli } & \multicolumn{3}{|c|}{ S. aureus } & \multicolumn{3}{|c|}{ C. albicans } \\
\hline & $1 \%$ & $3 \%$ & $5 \%$ & $1 \%$ & $3 \%$ & $5 \%$ & $1 \%$ & $3 \%$ & $5 \%$ \\
\hline $\mathrm{NT}_{1}$ & - & - & - & - & $7.10 \pm 0.00$ & $8.00 \pm 0.00$ & - & $7.00 \pm 0.00$ & $8.00 \pm 0.00$ \\
\hline $\mathrm{NT}_{2}$ & $7.45 \pm 0.00$ & $8.75 \pm 0.00$ & $9.10 \pm 0.00$ & - & - & - & - & - & $6.70 \pm 0.00$ \\
\hline $\mathrm{NT}_{3}$ & $8.07 \pm 1.91$ & $18.0 \pm 1.75$ & $20.9 \pm 1.55$ & $9.90 \pm 0.35$ & $15.4 \pm 4.56$ & $17.1 \pm 6.57$ & - & $6.35 \pm 0.00$ & $13.6 \pm 0.00$ \\
\hline $\mathrm{NT}_{4}$ & $10.1 \pm 2.89$ & $7.50 \pm 0.21$ & $8.10 \pm 6.57$ & - & - & - & - & $7.00 \pm 0.00$ & $6.00 \pm 0.00$ \\
\hline $\mathrm{NT}_{5}$ & - & - & - & $7.20 \pm 0.00$ & $7.55 \pm 0.00$ & $10.1 \pm 0.00$ & - & - & - \\
\hline $\mathrm{NT}_{6}$ & $6.95 \pm 0.00$ & $7.50 \pm 0.00$ & $7.58 \pm 0.00$ & - & - & - & - & - & - \\
\hline $\mathrm{NT}_{7}$ & - & $7.90 \pm 0.00$ & $8.50 \pm 0.00$ & - & $6.05 \pm 0.00$ & $8.47 \pm 0.00$ & - & - & $6.50 \pm 0.00$ \\
\hline $\mathrm{NT}_{8}$ & - & - & $7.35 \pm 0.00$ & - & - & - & - & - & - \\
\hline $\mathrm{NT}_{9}$ & - & - & - & $7.20 \pm 0.00$ & $12.4 \pm 0.00$ & $12.8 \pm 0.00$ & - & $6.60 \pm 0.00$ & $11.1 \pm 0.00$ \\
\hline
\end{tabular}

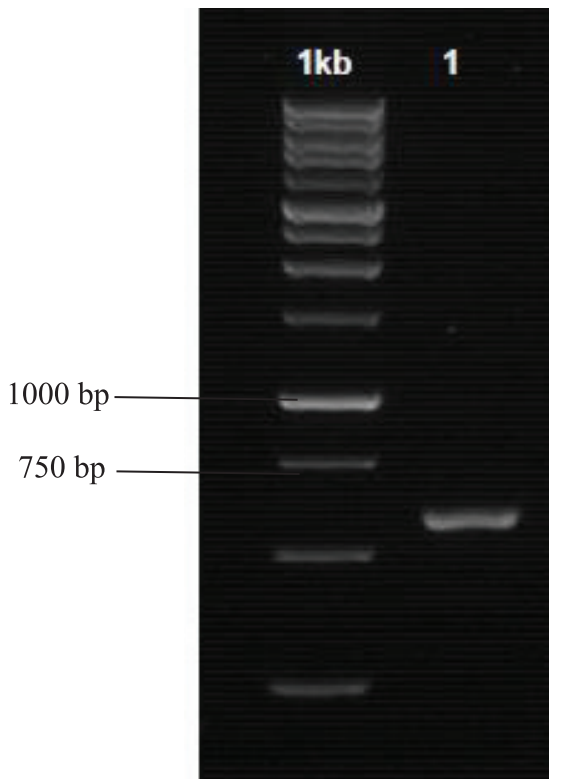

Figure 1. PCR product of ITS gene from NT3 isolate derived from Padina $\mathrm{sp}$. There is a $640 \mathrm{bp}$ band from the sample and the marker is $1 \mathrm{~kb}$.

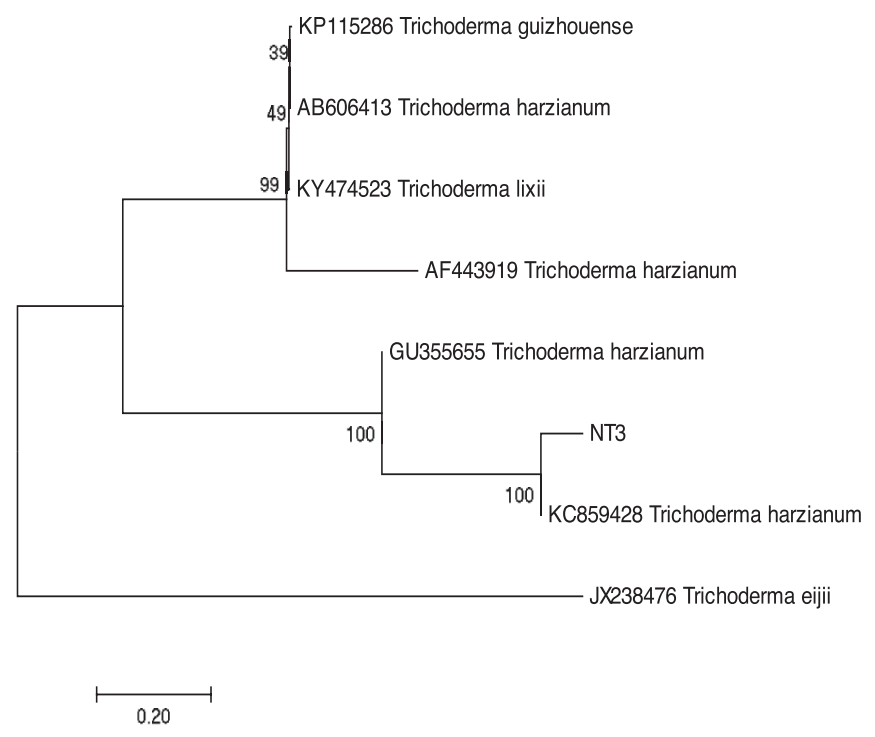

Figure 2. The phylogenetic tree inferred using the neighbor-joining method of ITS sequence of $\mathrm{NT}_{3}$ endophytic fungal from Padina sp. and its allied taxa. 
Table 2. Phytochemical screening of EtOAc extract of endophytic fungi from marine algae Padina sp.

\begin{tabular}{lccc}
\hline \multirow{2}{*}{ Fungi code } & \multicolumn{3}{c}{ Secondary metabolite compound } \\
\cline { 2 - 4 } & Alkaloid & Phenolic & Terpenoid/Steroid \\
\hline $\mathrm{NT}_{1}$ & $(+)$ & $(+)$ & $(-)$ \\
$\mathrm{NT}_{2}$ & $(+)$ & $(+)$ & $(-)$ \\
$\mathrm{NT}_{3}$ & $(-)$ & $(-)$ & $(-)$ \\
$\mathrm{NT}_{4}$ & $(+)$ & $(+)$ & $(+)$ \\
$\mathrm{NT}_{5}$ & $(-)$ & $(-)$ & $(-)$ \\
$\mathrm{NT}_{6}$ & $(+)$ & $(-)$ & $(-)$ \\
$\mathrm{NT}_{7}$ & $(+)$ & $(+)$ & $(+)$ \\
$\mathrm{NT}_{8}$ & $(+)$ & $(+)$ & $(+)$ \\
$\mathrm{NT}_{9}$ & $(+)$ & $(+)$ & $(+)$ \\
\hline
\end{tabular}

Table 3. Estimation of evolutionary divergence between sequences using the Kimura 2-parameter model.

\begin{tabular}{llccccccc}
\hline & & $\mathbf{1}$ & $\mathbf{2}$ & $\mathbf{3}$ & $\mathbf{4}$ & $\mathbf{5}$ & $\mathbf{6}$ & $\mathbf{7}$ \\
\hline 1 & NT3 & & & & & & \\
2 & KY474523 Trichoderma lixii & 1.227 & & & & & & \\
3 & KP115286 Trichoderma guizhouense & 1.217 & 0.004 & & & & & \\
4 & GU355655 Trichoderma harzianum & 0.230 & 0.585 & 0.585 & & & & \\
5 & AB606413 Trichoderma harzianum & 1.217 & 0.002 & 0.002 & 0.580 & & & \\
6 & AF443919 Trichoderma harzianum & 1.111 & 0.233 & 0.236 & 1.223 & 0.236 & \\
7 & KC859428 Trichoderma harzianum & 0.039 & 1.072 & 1.064 & 0.283 & 1.064 & 0.975 & \\
8 & JX238476_Trichoderma_eijii & 1.904 & 1.473 & 1.488 & 1.657 & 1.473 & 1.655 & 1.805 \\
\hline
\end{tabular}

microorganism living in almost all kinds of soil, varied habitat, and is a saprophyte (Harman, 2000).

Neighbor-joining method was used for constructing the phylogenetic tree with a bootstrap value of 1,000 (Fig. 2). In this tree, $\mathrm{NT}_{3}$ is clustered together with $T$. harzianum $\mathrm{KC} 859428$ from Kerala (India). The genetic difference between them is only $3.9 \%$ according to the Kimura 2-parameter model (Table 3). Trichoderma harzianum is actually synonym to T. lixii and T. guizhouense (Chaverria et al., 2003; 2015). Using the entire ITS region, the threshold value of $99 \%$ similarity is set for distinguishing species in a genus (Garnica et al., 2016). This implies that the classification of the genus Trichoderma needs to be revisited. Little is known about the bioactive compound of T. harzianum as an antibacterial agent. However, a metabolite of a genus of Trichoderma repeatedly shows interesting bioactivity against pathogenic bacteria. Aspereline A isolated from Trichoderma sp., for example, has bioactivity against $S$. aureus and $E$. coli with MIC $<100 \mu \mathrm{g} / \mathrm{ml}$ (Ren et al., 2009). In addition, Trichoderin A isolated from Trichoderma sp. has a potential bioactive against Mycobacterium smegmatis, M. bovis, and M. tuberculosis with MIC $<2.0 \mu \mathrm{g} / \mathrm{ml}$ (Pruksakorn et al., 2010).

Study of Ghisalberti and Rowland (1993) about antifungal metabolites from $T$. harzianum revealed that octaketide keto diol and octaketide-derived compounds have strong antifungal against Rhizoctonia solani. These compounds are polyketide group, which is responsible for their antimicrobial properties (Hermosa et al., 2014). Phytochemical screening of extracts from nine isolates showed alkaloid, phenolic, triterpenoid, and steroid compounds (Table 2). However, the $\mathrm{NT}_{3}$ extract showed negative results for this test. Therefore, polyketide was estimated as a compound for providing an antimicrobial property of T. harzianum.

\section{CONCLUSION}

Endophytic fungal $\mathrm{NT}_{3}$ from Padina sp. showed potential bioactive against several pathogenic microbes $S$. aureus, E. coli, and C. albicans. Molecular characterization indicated that $\mathrm{NT}_{3}$ was T. harzianum. Further research needs to be conducted to determine the bioactive compound that has a role in inhibiting the growth of these pathogenic microbes.

\section{ACKNOWLEDGMENTS}

This research was funded by Directorate General of Higher Education, Ministry of National Education, Indonesia, in the project "International Research Collaboration and Publication," No: 059/SP2H/LT/DPRM/IV/2018.

\section{CONFLICT OF INTEREST}

There is no conflict of interest.

\section{REFERENCES}

Artasasta MA, Yanwirasti DA, Handayani S. Cytotoxic activity screening of ethyl acetate fungal extracts derived from the marine sponge Neopetrosia chaliniformis AR-01. J Appl Pharm Sci, 2017; 7(12):174-8.

Ashok G, Senthilkumar G, Panneerselvam A. Diversity and seasonal variation of soil Fungi isolated from coastal area of Tuticorin Dt., Tamil Nadu, India. Int J Curr Microbiol App Sci, 2015; 4(10):161-78.

Atashpaz S, Khani S, Barzegari A, Barar J, Vahed S, Azarbaijani $\mathrm{R}$, Omidi Y. A robust universal method for extraction of genomic DNA from bacterial species. Microbiology, 2010; 79(4):538-42.

Bacon CW, White JF. Microbial endophytic. Marcel Dekker, New York and Basel, pp 1-487, 2000.

Bauer AW, Perry DM, Kirby WMM. Single-disk antibioticsensitivity testing of Staphylococci: an analysis of technique and results. Arch Intern Med, 1959; 104(2):208-16. 
Bugni TS, Ireland CM. Marine-derived fungi: a chemically and biologically diverse group of microorganisms. Nat Prod Rep, 2004; 21:143-63.

Chaverria P, Branco-Rocha F, Jaklitsch W, Gazis R, Degenkolb T, Samuels GJ. Systematics of the Trichoderma harzianum species complex and the re-identification of commercial biocontrol strains. Mycologia, 2015; 107(3):558-90.

Chaverria P, Castlebury LA, Samuels GJ, Mgeisera D. Multilocus phylogenetic structure within the Trichoderma harzianum/Hypocrea lixii complex. Mol Phylogenet Evol, 2003; 27(2):302-13; doi:10.1016/S10557903(02)00400-1

Ferrer C, Colom F, Frases S, Mulet E, Abad JL, Alió JL. Detection and identification of fungal pathogens by PCR and by ITS2 and 5.8S ribosomal DNA typing in ocular infections. J Clin Microb, 2001; 39(8):2873-9.

Flewelling AJ, Currie J, Gray CA, Johnson JA. Endophytes from marine macroalgae: promising sources of novel natural products. Curr Sci, 2015; 109:88-111.

Garnica S, Schön ME, Abarenkov K, Riess K, Liimatainen K, Niskanen T, Dima B, Soop K, Frøslev TB, Jeppesen TS, Peintner U, Kuhnert-Finkernagel R, Brandrud TE, Saar G, Oertel B, Ammirati JF. Determining threshold values for barcoding fungi: lessons from cortinarius (Basidiomycota), a highly diverse and widespread ectomycorrhizal genus. FEMS Microbiol Ecol, 2016; 92(4):fiw045; doi:10.1093/femsec/fiw045.

Ghisalberti EL, Rowland CY. Antifungal metabolites from Trichoderma harzianum. J Nat Prod, 1993; 56(10):1799-804.

Handayani D, Aminah I. Antibacterial and cytotoxic activities of ethyl acetate extract of symbiotic fungi from West Sumatra marine sponge Acanthrongylophora ingens. J Appl Pharm Sci, 2017; 7(02):237-40.

Handayani D, Artasasta MA. Antibacterial and cytotoxic activities screening of symbiotic fungi extracts isolated from marine sponge Neopetrosia chaliniformis AR-01. J Appl Pharm Sci, 2017; 7(05):066-9.

Handayani D, Ornando R, Rustini R. Antimicrobial activity screening of symbiotic fungi from marine sponge Petrosia nigrans collected from South Coast of West Sumatera Indonesia. Int J Pharmacogn Phytochem Res, 2016; 8(4):623-6.

Handayani D, Rasyid W, Rustini, Zainudin EN, Hertiani T. Cytotoxic activity screening of fungal extracts derived from the West Sumatran marine sponge Haliclona fascigera to several human cell lines: Hela, WiDr, T47D, and Vero. J Appl Pharm Sci, 2018; 8(01):055-8.

Harman GE. Myths and dogmas of biocontrol changes in perceptions derived from research on Trichoderma harzinum T-22. Plant Dis, 2000; 84(04):377-93.

Hawksworth DI. The fungal dimension of biodiversity: magnitude, significance, and conservation. Mycol Res, 1991; 95:641-55.
Hermosa R, Cardoza RE, Rubio MB, Gutierrez S, Monte E. Chapter 10: Secondary metabolism and antimicrobial metabolites of Trichoderma. In: Biotechnology and biology of Trichoderma. Elsevier B.V., Netherlands, pp 125-37, 2014.

Kjer J, Debbab A, Aly AH, Proksch P. Methods for isolation of marine-derived endophytic fungi and their bioactive secondary products. Nat Protoc, 2010; 5(3):479-90.

Kumar S, Stecher G, Tamura K. MEGA7: molecular evolutionary genetics analysis version 7.0 for bigger datasets. Mol Biol Evol, 2016; 33(7):1870-4.

Pruksakorn P, Arai M, Kotoku N, Vilcheze C, Baughn AD, Moodley P, Jacobs WR Jr, Kobayashi M. Trichoderins, novel aminolipoptides from marine sponge-derived Trichoderma $s p$. Are active against dormant mycobacteria. Bior Medi Chem Lett, 2010; 20:3658-63.

Rateb ME, Ebel R. Secondary metabolites of fungi from marine habitats. Nat Prod Rep, 2011; 28:290-344.

Ren J, Xue C, Tian L, Xu M, Chen J, Deng Z, Proksch P, Wenhan L. Asperelines A-F, peptaibols from the marine-derived fungus Trichoderma asperellum. J Nat Prod, 2009; 72(6):1036-44.

Singh RP, Kumari P, Reddy CRK. Mini review: Antimicrobial compounds from seaweeds-associated bacteria and fungi. Appl Microbiol Biotechnol, 2014; 99(4):1571-86; doi:10.1007/s00253-014-6334-y.

Strobel G, Daisy B. Bioprospecting for microbial endophytes and their natural products. Microbiol Mol Biol Rev, 2003; 67:491-502.

Tiwari P, Kumar B, Kaur M, Kaur G, Kaur H. Phytochemical screening and extraction: a review. Int Pharm Sci, 2011; 1(1):98-106.

Wong C, Proksch P, Tan LT, Lihan S, Mujahid A, Müller M. Isolation, identification and screening of antimicrobial properties of the marine-derived endophytic fungi from marine brown seaweed. Microbiol Indones, 2015; 9(4):141-9.

Zhang P, Mandi A, Li XM, Du FY, Wang JN, Li X, Kurtan T, Wang BG. Varioxepine A, a 3H-Oxepine-containing alkaloid with a new oxacage from the marine algal-derived endophytic fungus Paecilomyces variotii. Org Lett, 2014; 1(2):A-D.

\section{How to cite this article:}

Handayani D, Ananda N, Ade Artasasta M, Ruslan R, Fadriyanti $\mathrm{O}$, Tallei TE. Antimicrobial activity screening of endophytic fungi extracts isolated from brown algae Padina sp. J Appl Pharm Sci, 2019; 9(03):009-013. 